Social Work \& Education

(C) SW\&E, 2018

\author{
Yuriy Bryndikov, \\ PhD in psychological sciences, \\ Associate professor, \\ Department of social work and \\ social pedagogy, \\ Khmelnytskyi national university \\ Khmelnytskyi, Ukraine \\ bryndik@i.ua
}

\section{Юрий Бриндіков,}

кандидат психологічних наук,

дочент,

кафедра соиіальної роботи $i$

соиіальної педагогіки,

Хмельницький національний

університет

м. Хмельницький, Украӥна

УДК 364-786:159.9.072: 355.292

DOI: $10.25128 / 2520-6230.18 .1 .1$

Article history:

Received: February 21, 2018

1st Revision: March 15, 2018

Accepted: March 28, 2018
Bryndikov, Y. (2018). Ігрові технології : суть, можливості роботи 3 військовослужбовцями учасниками бойових дій, Social Work and Education, Vol. 5, No. 1., pp. 8-17.

\section{ІГРОВІ ТЕХНОЛОГІЇ : СУТЬ, МОЖЛИВОСТІ РОБОТИ 3 ВІЙСЬКОВОСЛУЖБОВЦЯМИ - УЧАСНИКАМИ БОЙОВИХ ДІЙ}

АНОТАЦІЯ. У статті проаналізовано загальні підходи до проблеми застосування ігрових технологій у роботі 3 військовослужбовцями учасниками бойових дій. У процесі дослідження представлено різні наукові підходи до сутності поняття «гра», що $\epsilon$ особливим педагогічним творінням; проявом індивідуальної та колективної ігрової діяльності; вираженням ставлення людини до події, процесів, явищ; засобом отримання соціального досвіду.

Охарактеризовано ігрові технології як групу методів і прийомів організації реабілітаційного процесу у формі різних ігор. Перевагами ігрових технологій при проведенні реабілітації військовослужбовці визначено можливості отримувати знання і формувати відповідні уміння і навички; приймати рішення; оцінювати власні дії i дії партнерів; розробляти стратегію i тактику власних дій. Встановлено, що при проведенні будьяких видів ігор 3 комбатантами необхідно дотримуватися поетапної технології, що передбачає підготовку до проведення заняття в ігровій формі; безпосереднє проведення гри та аналітичнооцінювальний етап. Увагу зосереджено на принципах гри, які $\epsilon$ обов'язковими i взаємопов'язаними між собою - імітаційного моделювання конкретних умов; проблемності змісту ділової гри; спільної діяльності учасників в умовах рольової взаємодії; діалогічного спілкування i взаємодії партнерів по грі; двоплановості ігрової діяльності.

Ключові слова: гра; ігрові технології; військовослужбовці - учасники бойових дій. 


\section{Вступ}

Професійна діяльність військовослужбовців, які беруть участь в антитерористичній операції на Сході України, відбувається в надзвичайно складних екстремальних умовах, які характеризуються високою інтенсивністю, напруженістю, швидкоплинністю, можливістю виникнення небезпечних для життя ситуацій. Це призводить до появи у військовослужбовців різних психічних розладів - стресових, емоційних, деструктивних, які призводять до особистісної трансформації комбатантів, формування перекрученої, патологічної картини світу, розвитку агресивної, конфліктної поведінки. Всі ці зміни негативно впливають на фізичний і психосоматичний стан військовослужбовців, а це, у свою чергу, знижує ефективність життєдіяльності вже в мирних умовах.

Підтримуючи науковців (Кокун О. М., 2017), ми переконані, що у значної частини осіб, які пережили психотравмувальні події, проблеми у сфері психічного здоров'я виникатимуть не одразу, а можуть з'явитися за якийсь час. Варто пам'ятати, що ці проблеми можуть проявитися не лише у формі посттравматичних стресових розладів (ПТСР), а й у інших формах, таких як: зловживання психоактивними речовинами, депресії, тривожні розлади, порушення контролю, спалахах злості тощо. Це вимагає оперативної оцінки стану розладів, прогнозу їх розвитку, проведення лікувальних і реабілітаційних заходів. Звідси виникає потреба у пошуку ефективних методів реабілітації комбатантів, одним із яких ми вважаємо ігрові технології - групу методів і прийомів організації реабілітаційного процесу у формі різних ігор.

Особливості подолання стресових розладів, ПТСР у військовослужбовців представлені дослідженнями Н. Алаликіної, О. Блінова, В. Знакова, Л. Смірнової, С. Сукіасяна та інших. Встановлено, що розробкою методологічних аспектів ігрових технологій займалися як зарубіжні (А. Бурлак, С. Котельников, М. Чистякова, Г. Щедровицький та інші), так і українські вчені (С. Довбня, С. Жицька, I. Мельничук, С. Поляков, О. Федоренко та інші). Однак, попри їх загальний доробок, варто констатувати нестачу теоретичного i практичного матеріалу, а також методологічних розробок щодо аналізу можливостей ігрових технологій у реабілітації військовослужбовців - учасників бойових дій.

Мета - охарактеризувати суть та можливості застосування ігрових технологій у роботі з військовослужбовцями - учасниками бойових дій.

Завдання дослідження: розкрити зміст понять «гра», «ігрові технології»; визначити можливості застосування ігрових технологій у роботі 3 військовослужбовцями - учасниками бойових дій.

\section{Методологія дослідження}

Під час визначення досліджуваної проблеми ми застосовували методи аналізу і синтезу, порівняння та узагальнення, теоретичні методи, пов'язані 3 вивченням наукової літератури, періодичних видань, довідкову педагогічну, психологічну, філософську літературу. Пошук інформації здійснювався в електронних базах даних, таких як Google Scholar, Web of Science, українських i зарубіжних веб-сайтах, присвячених реабілітації військовослужбовців учасників бойових дій. 


\section{Основна частина}

У зв'язку з тим, що ігрові технології є ключовим поняттям нашого науковопедагогічного дослідження, виникає необхідність у тлумаченні понять цієї дефініції - «технологій» і «гри». У «Тлумачному словнику української мови» технологія визначається як сукупність знань, відомостей про послідовність окремих виробничих операцій у процесі виробництва чогось; начальний предмет, що викладає ці знання, відомості; сукупність способів обробки або переробки матеріалів, виготовлення виробів, проведення різних операцій тощо (Бусел В. Т., 2007 , с. 445). У філософії технологія трактується як засіб досягнення визначеної мети, як процес перетворення будь-якої діяльності, а технологічність - як структурна розчленованість, упорядкованість, доцільна організованість будьякого процесу соціальної діяльності на відміну від стихійних природних процесів. У процесуальному розумінні технологія відповідає на питання: «Як зробити (з чого і якими способами)?» (Степин В. С., 2001).

У науково-довідковій літературі «гру» трактують по-різному. Так, у «Великому тлумачному словнику» «гра» розуміється як заняття, що підпорядковане сукупності правил і прийомів, або базується на певних умовах, що розкриває іiі процесуальний зміст. Багатогранність ігрової діяльності, яка розвиває, виховує, соціалізує та концентрується на конкретній меті, полягає у збагаченні особи знаннями, уміннями, досвідом та є процесом опанування знань, досвіду з урахуванням досягнень і недоліків минулого, набуття навичок, умінь виконувати певні дії, виховувати та виробляти в собі певні якості, риси, уміння (Бусел В. Т., 2007, с. 706).

3 позиції філософії, «гра» - це одна 3 головних і найдавніших форм естетичної діяльності - неутилітарної, яку здійснюють заради неї самої і яка доставляє іï учасникам і глядачам естетичну насолоду, задоволення, радість. Принципово непродуктивний i нераціональний характер гри 3 давніх-давен пов'язував іiі із сакральними і культовими дійствами, 3 мистецтвом, наділяв таємничими, магічними сенсами (Степин В. С., 2001). 3 погляду культурології, гра - це форма вільного самовираження людини, що припускає реальну відкритість світу можливого і розгортається або у вигляді змагання, або у вигляді подання будь-яких ситуацій, смислів і станів. Сучасна культурологічна думка висуває гру в якості самостійної галузі вивчення і обгрунтовує наскрізне значення гри в розвитку основних культурних форм людської діяльності мистецтві, науці, філософії, політиці (Кононенко Б. И., 2003).

У психологічному контексті, гра $є$ активністю індивіда, спрямована на умовне моделювання якоїсь розгорнутої діяльності, для людини - формою діяльності в умовних ситуаціях, спрямованою на відтворення і засвоєння суспільного досвіду, фіксованого в соціально закріплених способах здійснення предметних дій, у предметах науки і культури (Головин С. Ю., 1998). У «Енциклопедії освіти» гра розглядається як вид креативної діяльності людини, у процесі якої в уявній формі відтворюються способи дій з предметами, стосунки між людьми, норми соціального життя та культурні надбання людства, які характеризують історично досягнутий рівень розвитку суспільства (Кремень В. Г., 2008, с. 139-140). 
Представимо феномен гри з різних наукових підходів (табл. 1).

Таблиця 1

Визначення гри з різних наукових підходів

\begin{tabular}{|c|c|}
\hline Автор & Змістове наповнення поняття «гра» \\
\hline А. Бурлака & $\begin{array}{l}\text { Гра - метод нейтралізації фрустраційного комплексу в } \\
\text { реабілітаційно-адаптаційних i рекреаційних процесах } \\
\text { військовослужбовців (Бурлак А. М., 2003) }\end{array}$ \\
\hline С. Довбня & $\begin{array}{l}\text { «Гра - це конкретний прояв індивідуальної та колективної } \\
\text { ігрової діяльності, яка має }\end{array}$ \\
\hline А. Петровський & $\begin{array}{l}\text { Гра володіє «можливостями досягнення цілей навчання } \\
\text { виховання, що не можуть бути надані іншими, традиційними } \\
\text { чи новими формами і методами навчання» (Аванесов В. С., } \\
\text { 1986, с. 209) }\end{array}$ \\
\hline С. Рубінштейн & $\begin{array}{l}\text { Гра є вираженням певного ставлення } \\
\text { навколишньої дійсності. «Суть гри }- \text { у } \\
\text { відображаючи, здатності, } \\
\text { виявляючись у грі, ця сама загальна людська здатність } \\
\text { вперше у грі і формується. Уперше формується і виявляється } \\
\text { потреба людини впливати на світ - у цьому основне, } \\
\text { центральне і саме загальне значення гри» (Рубинштейн С. Л., } \\
\text { 2000, с. 589) }\end{array}$ \\
\hline О. Федоренко & $\begin{array}{l}\text { Гра допомагає здобути не тільки певний соціальний досвід } \\
\text { фахівця, але i соціальний досвід: навички соціальної } \\
\text { взаємодії, управління людьми, формується психологічна } \\
\text { спрямованість у діяльності і ставлення до неї, уміння } \\
\text { керувати і підкорятися (Федоренко О. І., 2014) }\end{array}$ \\
\hline Г. Щедровицький & $\begin{array}{l}\text { Гра створена суспільством для управління розвитком } \\
\text { особистості: у цьому плані вона є особливим педагогічним } \\
\text { творінням (Щедровицкий Г. П., 1983) }\end{array}$ \\
\hline
\end{tabular}

Отже, при різноманітності підходів до сутності гри, приємно відзначити, що дослідники вважають цей метод корисний не лише для дітей, а й для дорослих, оскільки він допомагає ефективніше соціалізуватися, адаптуватися до нових умов життєдіяльності, вдосконалюючи при цьому певні знання, уміння і навички.

Висока ефективність гри обумовлена вагомими перевагами в порівнянні 3 традиційними. Деякі з них хотілося б виділити особливо:

- допомагає виразити себе в середовищі, реалізувати ті сторони духовного потенціалу людини, які не можуть бути затребувані при її звичайній діяльності;

— конструює і створює уявний простір, ситуації, рольовий супровід і шляхом заміщення втілює нереалізовані бажання, що формують фрустраційний комплекс;

- загострюють сприйняття інших людей і розвивають здатність оцінювати i реагувати на їхні потреби та інтереси (Бурлак А. М., 2003); 
- мотивує людину, сприяє соціалізації та професійному розвитку, надає можливості перевірити на практиці, розвинути й інтегрувати сформовані переконання, навички та здібності;

- допомагає побачити людині особливості власного життя та відчути включеність в оточуючий світ у цілому;

- спонукає краще зрозуміти i навчитися використовувати всю складність психічних, соціальних та організаційних процесів спілкування між людьми;

- спонукає учасників тренувати особистісні навички, необхідні у груповому процесі, а саме: диференційованого сприйняття, відкритої комунікації, постановки вимог, прийняття рішень, допомоги іншим, співробітництва, пошуку можливостей самодопомоги, особистісної відповідальності;

- сприяє зняттю деяких захисних механізмів, оскільки інструкції i дотримання групових норм надають можливість моделювати у грі складні форми поведінки (Мельничук I. М., 2010);

- у грі можна нехтувати деталями, виключити з інформаційного масиву так званий «шум», породжений властивостями реальних процесів, які не відносяться до справи;

- гра дає змогу «жити швидше» або «повільніше», прискорювати i уповільнювати хід подій. У обстановці умовної практики, яку створює гра, можна за декілька годин «прожити» декілька років;

- у грі можна кілька разів програвати одну і ту ж ситуацію, підходячи до іï рішення кожного разу по-новому;

- різний масштаб охоплення ігрових ланок може значно скоротити терміни пошуку принципових рішень у різних умовах (Поляков С. Ю., 2012).

Зупинимося на перевагах ігрових технологій при проведенні реабілітації військовослужбовці, оскільки вони:

- отримують необхідну інформацію (знання, факти, історії) і формують відповідні уміння і навички;

— приймають рішення, за допомогою розробки, зміни і корекції плану дій;

— оцінюють власні дії і дії партнерів;

- розробляють тактику і стратегію своїх дій;

- вивчають структуру соціальної системи за умови розробки імітаційної гри (Швейцер А, 1993, с. 25);

I. Мельничук вважає, що перші серйозні ігри дорослих людей були військовими іграми, йдеться про військові маневри - це глобальні ігри за особливими правилами, а гра в шахи є предком сучасних імітаційних ігор. Сучасні ділові ігри беруть початок із 1930-х років, коли в колишньому СРСР запроваджувалася наукова організація праці для вирішення складних управлінських завдань. Наприкінці 50-х років XX ст. ділові ігри отримали нове народження у США у зв'язку з вирішенням, знову ж таки, військових проблем (Мельничук I. М., 2010).

Слід зазначити, що у військовослужбовців - учасників бойових дій свідомість відрізняється від свідомості нормальної людини великою кількістю негативного енергоінформаційного матеріалу. Пам'ять про психотравмувальні ситуації підтримує високий рівень блокування енергоінформаційних каналів, що, в свою чергу, призводить до спотворення і негативного забарвлення будь-якої інформації. Ігрова діяльність допомагає змінити структуру енергоінформаційного обміну, оскільки під час гри людина стає самою собою, знижується ступінь блокування енергоінформаційних каналів органів відчуттів, збільшується позитивний інформаційний енергообмін із зовнішнім середовищем, що дає змогу отримати внутрішню позитивну енергію. 
На початкових етапах здійснення реабілітації, коли вивчають ігрові інтереси комбатантів, необхідно підбирати такий ігровий матеріал, що допоможе домогтися максимально позитивної енергоінформаційної наповненості свідомості комбатантів. У подальшому загальний стан буде покращуватися, зменшуючи при цьому деструктивні емоційні відчуття і отримуючи позитивні емоції. Саме в цей час необхідно розробляти ігри для індивідуальної корекції психоемоційного стану військовослужбовців.

У роботі з комбатантами фахівці (соціальні працівники, психологи) мають враховувати методичні вимоги до проведення ігор. Підтримуючи думку О. Федоренко (Федоренко О. I., 2014), вважаємо, що, по-перше, гра має бути максимально наближена до реальних професійних умов. По-друге, продуктивна гра створює особливу атмосферу пошуку та невимушеності. По-третє, у грі мають бути чітко сформульовані завдання, зрозумілі всім іiі учасникам, визначені зміст і правила гри. По-четверте, у грі необхідно виявляти й аналізувати можливі варіанти розв'язання поставленої проблеми.

Вважаємо, що при проведенні ігор з військовослужбовцями - учасниками бойових дій необхідно дотримуватися певної технології. За основу ми взяли поетапну методику застосування інтерактивних технологій, розроблену I. Мельничук (Мельничук I. М., 2010).

1. Підготовчий етап зосереджений на підготовці до проведення ігрового заняття. Для цього необхідно чітко визначити мету кожної гри та час, що відводиться на іiі проведення; встановити відповідність змістового наповнення гри загальній меті заняття; розробити власний чи адаптувати готовий сценарій гри; структурувати етапи ігрової взаємодії; забезпечити необхідне обладнання; розробити чітку покрокову інструкцію для військовослужбовців - учасників ігрової взаємодії (мета, завдання, правила, умови, ігрові діï).

2. Ігровий етап передбачає безпосереднє проведення гри, під час якої військовослужбовці виявляють внутрішню (психологічну), зовнішню (фізичну) та соціальну активності. При цьому діяльнісна активність регулюється усвідомлюваною метою і характеризується такими ознаками, як-от: передбачення результату та усвідомлення можливості його досягнення; обгрунтоване планування дій; вибір раціональних форм, методів, орієнтирів та засобів у міжособистісних відносинах; оцінювання процесу та результатів своєї праці, що потребує вмінь діагностувати, прогнозувати, стимулювати діяльність, підходити до неї комплексно, системно, цілісно і надає змогу комбатантам перевірити доцільність діяльності та ііі відповідність поставленій меті.

3. Підсумковий етап передбачає рефлексію, узагальнення результатів та формулювання висновків гри. На цьому етапі військовослужбовці визначають позитивні аспекти результативності гри для власного особистісного і професійного зростання. У свою чергу, ведучий аналізує проблеми, упущення та визначає шляхи вдосконалення ігрової взаємодії учасників для подальшого використання апробованої методики.

Ефективність гри залежатиме від принципів, які є обов'язковими, оскільки вони допоможуть організувати і провести гру ефективно й 3 користю для іiі учасників. До таких колектив авторів навчального посібника (Аванесов В. С., 1986) відносять:

- принцип імітаційного моделювання конкретних умов i динаміки професійної діяльності, а також моделювання змісту цієї діяльності. Відповідно до цього принципу створюється як імітаційна модель умов діяльності, так і ігрова модель професійної діяльності. Розгортання цих двох моделей на етапі проведення гри створює предметний і соціальний контексти майбутньої діяльності; 
- принцип проблемності змісту ділової гри і процесу його розгортання в пізнавальній діяльності комбатантів. Цей принцип означає, що в предметний матеріал ділової гри необхідно закладати навчальні проблеми, у вигляді системи ігрових завдань для учасників. Характерною рисою таких завдань $\epsilon$ те, що в них міститься той чи інший тип протиріч, характерний для проблемного навчання. При зіткненні 3 завданням подібного роду комбатант починає відчувати стан ускладнення, виникнення запитань, пізнавальної потреби, що спонукає його виявити протиріччя і вийти з цього стану - проблемної ситуації;

- принцип спільної діяльності учасників в умовах рольової взаємодії, розподілу й інтеграції тих професійних функцій фахівців, що імітуються у грі. Гра передбачає спілкування і взаємодію учасників, що можуть виникнути тільки при наявності декількох суб'єктів спілкування. У цьому випадку реалізується методологічна схема «суб'єкт-суб'єктних» відносин, що виступає необхідною умовою розвитку психічних процесів, мислення фахівця;

- принцип діалогічного спілкування і взаємодії партнерів по грі як необхідна умова рішення навчальних задач, підготовки i прийняття погоджених рішень, розвитку пізнавальної активності особистості. Переживання проблемної ситуації ситуації взаємодії з об'єктом - є «запитальним» станом учасника гри. Обумовлене проблемним змістом ділової гри, питання може бути задано партнеру по грі, утягуючи його тим самим у спілкування, спрямоване на спільний пошук потрібної відповіді. Відповідь, зустрічне питання або система міркувань партнера обумовлюють спільну діяльність у напрямку ухвалення рішення. Навіть при наявності однакових умов і однакової інформації люди неоднозначно інтерпретують ïx зміст, що створює необхідні передумови для зародження діалогу, обговорення, дискусії, узгодження позицій і інтересів;

- принцип двоплановості ігрової діяльності. Сутність цього принципу полягає в тому, що діяльність щодо формування і розвитку особистості фахівця реалізується в ігровій формі, що дає змогу учасникам інтелектуально й емоційно розкритися, проявити творчу ініціативу. Знаходячись у ситуації, що заміняє умови професійної діяльності, комбатант повинен оволодіти апаратом здійснення цієї діяльності - системою знань, умінь, навичок, відносин з іншими людьми.

Названі вище принципи взаємопов'язані між собою, кожен 3 них є логічним продовженням і розвитком іншого (Аванесов В. С., 1986, с. 212-216).

У грі прийняте рішення реалізується в розвитку (доопрацюванні, зміні, корекції) плану. Приймаючи участь у грі, реабілітовані оцінюють власні дії та дії партнерів. Вірно вибрані тактика і стратегія призводять до успіху в грі. Людина розуміє, чи є іiі дії ефективними, якщо ні, то дивиться, що зроблено не так, і шукає способи змінити стратегію (Бурлак А. М., 2003). Важливим для нашого дослідження $\epsilon$ висновки А. Бурлака (Бурлак А. М., 2003) щодо того, що в ігровій діяльності в боротьбі за виграш виникає стан азарту і виділяються ендорфіни, які впливають, як на психоемоційний стан, так і на весь організм в цілому. Таким чином, гра допомагає зменшити стрес і наслідки ПТСР.

\section{Висновки}

Проведений аналіз сутності ігрових технологій дав змогу визначити їхні можливості у роботі з військовослужбовцями - учасниками бойових дій при проведенні реабілітації останніх. По-перше, у реабілітованих підвищується інтерес до навчально-коректувальних занять і пов'язаних з ними проблем, які моделюються або проектуються за допомогою різних видів ігор. По-друге, у процесі проведення ігор формується особистісна позиція, що проявляється у формуванні моральних особистісних якостей військовослужбовців. По-третє, у 
комбатантів формується комплекс різноманітних умінь i навичок, які моделюються в процесі гри.

Перспективи подальших досліджень. Наші наступні публікації будуть акцентові на розкритті практичних аспектів організації і здійснення реабілітації військовослужбовців - учасників бойових дій засобами ігрових технологій.

\section{Лiтература}

Гончаренко, С. У. (1997). Український педагогічний словник. К., Либідь, 376. Аванесов, В. С. (1986). Основы педагогики и психологии высшей школы : учеб. пособ. М., Изд-во Моск. ун-та, 304.

Бурлак, А. М. (2003). Игровые технологии как средство социальнокультурной реабилитации военнослужащих : дис... канд. пед. наук : 13.00.05. М., РГБ, 204.

Бусел, В. Т. (2007). Великий тлумачний словник сучасної української мови. К., Ірпінь, Перун, 1736.

Головин, С. Ю. (1998). Словарь практического психолога. М., АСТ, Харвест, 800.

Довбня, С. О. (2011) Гра як історико-педагогічний феномен. Педагогічна освіта теорія і практика. (9), 245-249.

Кокун, О. М., Агаєв, Н. А., Пішко, І. О., Лозінська, Н. С., Остапчук, В. В. (2017). Психологічна робота з військовослужбовцями - учасниками АТО на етапі відновлення: методичний посібник. К., НДЦ ГП, 282.

Кононенко, Б. И. (2003). Большой толковый словарь по культурологии. М., Вече, АСТ, 511.

Кремень, В. Г. (2008). Енциклопедія освіти. К., Юрінком Інтер, 300.

Мельничук, I. М. (2010). Особливості застосування інтерактивних ігор у вищому навчальному закладі. Вісник Національної академії Державної прикордонної служби України. (4).

Поляков, С. Ю. (2012). Ігрове навчання як спосіб підвищення і розвитку творчих здібностей курсантів вищих військових навчальних закладів. Наука $i$ техніка Повітряних Сил Збройних Сил Украӥни. 3 (9), 189-193.

Рубинштейн, С. Л. (2000). Основы общей психологии. СПб., Питер, 705. 2659.

Стёпин В. С. (2001). Новая философская энциклопедия : В 4 тт. М., Мысль,

Федоренко, О. I. (2014). Використання ділових ігор при вивченні правових дисциплін у процесі підготовки майбутніх правоохоронців до професійної діяльності. Вісник Наџіонального університету оборони Украӥни. 4 (41), 129-134.

Швейцер, А. (1993). Упадок и возрождение культуры. М., Прометей, 512.

Щедровицкий, Г. П., Котельников, С. И. (1983). Организационнодеятельностная игра как новая форма организации и метод развития коллективной мыследеятельности. Нововведения в организациях. М., ВНИСИ, $33-53$. 


\title{
GAME TECHNOLOGIES: THE ESSENCE, POSSIBILITIES OF WORKING WITH THE SERVICEMEN THE COMBATANTS
}

\author{
Y. L. Bryndikov, $\mathrm{PhD}$ in psychological sciences, Associate professor, \\ Department of social work and social pedagogy, Khmelnytskyi national \\ university Khmelnytskyi, Ukraine \\ bryndik@i.ua
}

Abstract. The article analyzes the general approaches to the problem of the use of gaming technologies in working with the servicemen the combatants. There are presented in the research various scientific approaches to the essence of the concept of "game". It is a special pedagogical creation; a manifestation of individual and collective game activity; an expression of a person's attitude to an event, processes, phenomena; a mean of obtaining social experience.

It is characterized gaming technologies as a group of methods and techniques for organizing a rehabilitation process in the form of various games. The advantages of gaming technology during the rehabilitation of a serviceman are the ability to obtain knowledge and form appropriate skills; to make a decision; to evaluate own actions and actions of partners; to develop a strategy and tactics of their own actions. It is established that in conducting any kind of games with the combatants it is necessary to observe the technology. The technology involves three stages. The first stage focuses on the preparation for the conduct of a training session in a gaming form. It contains the content, game script, gameplay stages, clear step-by-step instruction for combatants. At the second stage, the game is being conducted directly. It is aimed at revealing the internal (psychological), external (physical) and social activity of the servicemen. The third stage is intended to summarize the results of the game, formulate the conclusions, and identify the positive aspects of the game's effectiveness to their personal growth by the soldiers.

The attention is focused on the principles of the game. They are binding and interrelated - simulating the simulation of specific conditions; problem content of the business game; joint activity of participants in conditions of role interaction; dialogic communication and interaction of the game partners; two-plan game activity.

Keywords: game; game technology; servicemen the combatants.

\section{References}

Avanesov, V. S. (1986). Osnovy pedagogiki i psihologii vysshej shkoly : ucheb. posob. [Fundamentals of pedagogy and psychology of higher education]. Moskva, Mosk. un-t Publ., 304 p. [In Russian].

Burlak, A. M. (2003). Igrovye tekhnologii kak sredstvo social'no-kul'turnoj reabilitacii voennosluzhashchih. Dis. kand. ped. nauk [Game technologies as a means of socio-cultural rehabilitation of servicemen: Cand. ped. sci. diss.]. Moskva, RGB, 204 p. [In Russian].

Busel, V. T. (2007). Velykyi tlumachnyi slovnyk suchasnoi ukrainskoi movy [Great explanatory dictionary of modern Ukrainian language]. Kiev, Irpin, Perun Publ., 1736 p. [In Ukrainian]. 
Golovin, S. YU. (1998). Slovar' prakticheskogo psihologa [Dictionary of practical psychologist]. Moskva, AST, Harvest Publ., 800 p. [In Russian].

Dovbnia, S. O. (2011) Hra yak istoryko-pedahohichnyi fenomen [Play as a historical and pedagogical phenomenon]. Pedahohichna osvita : teoriia i praktyka [Pedagogical Education: Theory and Practice], no. 9, pp. 245-249 [In Ukrainian].

Kokun, O. M., Ahaiev, N. A., Pishko, I. O., Lozinska, N. S., Ostapchuk, V. V. (2017). Psykholohichna robota z viiskovosluzhbovtsiamy uchasnykamy ATO na etapi vidnovlennia: metodychnyi posibnyk [Psychological work with troops - ATO participants at the stage of recovery: a methodological manual]. Kiev, NDTs HP Publ., 282 p. [In Ukrainian].

Kononenko, B. I. (2003). Bol'shoj tolkovyj slovar' po kul'turologii [Great Dictionary of Cultural Studies]. Moskva, Veche, AST Publ., 511 p. [In Russian].

Kremen, V. H. (2008). Entsyklopediia osvity [Encyclopedia of Education]. Kiev, Yurinkom Inter Publ., 300 p. [In Ukrainian].

Melnychuk, I. M. (2010). Osoblyvosti zastosuvannia interaktyvnykh ihor $u$ vyshchomu navchalnomu zakladi [Features of the use of interactive games in higher education]. Visnyk Natsionalnoi akademii Derzhavnoi prykordonnoi sluzhby Ukrainy [Bulletin of the National Academy of the State Border Guard Service of Ukraine], no. 4 [In Ukrainian].

Poliakov, S. Yu. (2012). Ihrove navchannia yak sposib pidvyshchennia $i$ rozvytku tvorchykh zdibnostei kursantiv vyshchykh viiskovykh navchalnykh zakladiv [Game teaching as a way to enhance and develop the creative abilities of cadets of higher military educational institutions]. Nauka i tekhnika Povitrianykh Syl Zbroinykh Syl Ukrainy [Science and Technology of the Air Forces of the Armed Forces of Ukraine], no. 3 (9), pp. 189-193 [In Ukrainian].

Rubinshtejn, S. L. (2000). Osnovy obshchej psihologii [Fundamentals of general psychology]. Piter, SPb Publ., 705 p. [In Russian].

Styopin V. S. (2001). Novaya filosofskaya ehnciklopediya : $V 4 \mathrm{tt}$. [New Philosophical Encyclopedia]. Moskva, Mysl' Publ., 2659 p. [In Russian].

Fedorenko, O. I. (2014). Vykorystannia dilovykh ihor pry vyvchenni pravovykh dystsyplin u protsesi pidhotovky maibutnikh pravookhorontsiv do profesiinoi diialnosti [Use of business games in the study of legal disciplines in the process of preparing future law enforcement officers for professional activities.]. Visnyk Natsionalnoho universytetu oborony Ukrainy [Bulletin of the National Defense University of Ukraine], no. 4 (41), pp. 129-134 [In Ukrainian].

SHvejcer, A. (1993). Upadok i vozrozhdenie kul'tury [Decline and revival of culture]. Moskva, Prometej Publ., 512 p. [In Russian].

SHCHedrovickij, G. P., Kotel'nikov, S. I. (1983). Organizacionnodeyatel'nostnaya igra kak novaya forma organizacii $i$ metod razvitiya kollektivnoj mysledeyatel'nosti [Organizational-activity game as a new form of organization and method of development of collective thought activity]. Novovvedeniya $v$ organizaciyah [Innovations in organizations]. Moskva, VNISI Publ., pp. 33-53 [In Russian]. 
